\title{
Public Political Ecology: a community of praxis for Earth Stewardship
}

\author{
Tracey Osborne ${ }^{1}$ \\ University of Arizona, USA
}

\begin{abstract}
Political ecology is a powerful framework for analyzing the underlying causes of environmental change, yet underutilized for guiding an ethical response to the Anthropocene. In this article, I introduce Public Political Ecology as an approach for practicing engaged scholarship in this moment of ecological crisis. A political, ethical and educational project, public political ecology is influenced by Antonio Gramsci's work on the philosophy of praxis. It therefore operates from the understanding that ideas are a material force capable of transforming society in revolutionary ways, and through a community of praxis within which academics can play important roles by engaging more actively with broader publics. Innovations from public geographies such as participatory action research and mapping, service learning and social media offer important methodologies and tools for this approach. Public political ecology, then, is a means by which political ecologists can serve as Earth stewards and thus finally make good on the field's emancipatory claims.
\end{abstract}

Keywords: Political ecology, engaged scholarship, Earth Stewardship, public geography, praxis

\section{Résumé}

L'écologie politique est un cadre puissant pour analyser les causes sous-jacentes du changement environnemental, mais sous-utilisé pour guider une réponse éthique à l'Anthropocène. Dans cet article, je présente l'Écologie Politique Publique comme une approche pour pratiquer le travail engagé dans ce moment de crise écologique. Un projet politique, éthique et éducatif, l'écologie politique publique est influencée par le travail d'Antonio Gramsci sur la philosophie de la praxis. Cela implique donc que les idées sont une force matérielle capable de transformer la société de manière révolutionnaire et à travers une communauté de praxis dans laquelle les universitaires peuvent jouer un rôle important en s'engageant plus activement avec des publics plus larges. Les innovations du domaine des «géographies publiques» telles que la recherche et la cartographie participative, l'apprentissage en cours d'emploi et les médias sociaux offrent des méthodologies et des outils importants pour cette approche. L'écologie politique publique est donc un moyen par lequel les écologistes politiques peuvent servir de «intendants de la terre» et ainsi, finalement, se substituer aux revendications émancipatrices de l'écologiepolitique.

Mots-clés: écologie politique, travail académique engagé, intendants terrestres, géographie publique, praxis

\section{Resumen}

La ecología política es un marco poderoso para analizar las causas subyacentes del cambio ambiental. Sin embargo se ha utilizado poco para guiar una respuesta ética al Antropoceno. En este trabajo, presento la Ecología Política Publica como una forma de practicar la escolaridad comprometida en este momento de crisis ecológica. Un proyecto político, ético y educacional, la ecología política publica es inspirado por el trabajo de Antonio Gramsci en la filosofía de praxis que propone que las ideas sirven como una fuerza material capaz de transformar la sociedad en maneras revolucionarias y usa una comunidad de praxis dentro de la cual los académicos pueden tener un papel importante por estar mas involucrados con públicos mas extensos. Innovaciones de las geografías publicas como la investigación y mapeo acción-participativa, aprender a través del servicio, y los medios sociales ofrecen metodologías y herramientas importantes para esta practica. La

\footnotetext{
${ }^{1}$ Dr. Tracey Osborne, Associate Professor, School of Geography and Development, University of Arizona, Tucson AZ, USA. Email: tosborne "at" email.arizona.edu. This article is a significantly reworked version of the keynote address I delivered at the 2016 Dimensions of Political Ecology (DOPE) Conference. I would like to thank DOPE organizers for the invitation and opportunity to initially develop these ideas. I would also like to thank Jeffrey Banister, Jennifer Casolo, Sapana Doshi, Rebecca Lave, Diana Liverman, and Miranda Trimmier, as well as Simon Batterbury and anonymous referees for their insightful comments on earlier drafts of this article. All of the usual disclaimers apply.
} 
ecología política publica es un método que pueden utilizar los ecologistas políticos para ayudar en administrar la tierra y así por fin cumplir con la misión emancipadora del campo.

Palabras claves: Ecología política, escolaridad comprometida, administración de la tierra, geografía pública, praxis

\section{Introduction}

The potential power of a popularized political ecology is so great... [and] might make way for a very new world, emerging from these dark times when progressive politics in both human and non-human realms seem so painfully paralyzed. (Robbins 2012:4)

We live in an unprecedented time - the Age of the Anthropocene- that demands new and innovative forms of engaged scholarship (Sayre et al. 2013). As a term, the Anthropocene refers to the era in which the cumulative impact of humans on the planet threatens to destabilize the self-sustaining dimensions of Earth systems (Crutzen 2002a; Crutzen and Stoermer 2000). This era is characterized by a series of interconnected global ecological disruptions (including climate change, biodiversity and species loss, deforestation, ocean acidification, etc.), many of which have approached or exceeded safe planetary boundaries and which, if left unchecked, threaten to induce a sixth extinction (Barnosky et al. 2011; Kingsford et al. 2009; Rockström et al. 2009). While global in scale, these processes have local implications, often impacting marginalized communities most severely and deepening historically rooted injustices. Political ecology is a powerful approach for conceptualizing the underlying causes of environmental change, yet underutilized for guiding an ethical response to the Anthropocene. In this article, I discuss why this moment of ecological crisis requires a Public Political Ecology (PPE), by which I mean theoretically-informed engaged scholarship from a political ecology perspective that operates through a community of praxis and that is guided by an integrated and ethical view of Earth Stewardship. I write this article as a sort of manifesto for political ecologists, emphasizing not only the crucial need for a publicly engaged political ecology but also critically delineating associated meanings and practices of Earth Stewardship in this time of profound ecological disruption.

Calls for engaged scholarship to address environmental issues have become louder since the turn of the $21^{\text {st }}$ century. In the late 1990s, prominent environmental scientist and then President of the American Association of the Advancement of Science, Jane Lubchenco, challenged scientists to adopt "a new social contract" to prioritize research on the most pressing environmental problems and to share those results widely with policymakers and the public (1998). Ecologists, largely in conservation biology, have responded to the call through the Ecological Society of America's Earth Stewardship initiative, which attempts to bridge natural and social sciences, policymakers and civil society (Chapin III et al. 2011). Although the Earth Stewardship initiative is important for its orientation towards explicit action, attention to ethics and the value of local and Indigenous ways of knowing, it privileges ecological knowledge and sustainability science while largely ignoring political economy and the power relations so central for understanding the root causes of our current socio-ecological state (Ogden et al. 2013; Sayre et al. 2013). Such apolitical responses to the Anthropocene will always prove inadequate. It is only by understanding the deep interconnections of socio-ecological relations across scale, historically and geographically — by paying attention to power and political economic drivers, the building blocks of political ecology — that we can fully understand and respond to the challenges that face us in the Anthropocene (Ogden et al. 2013).

As an analytical framework, political ecology recognizes that environmental issues are not simply biophysical problems to be solved by markets or technological fixes. Rather, it understands environmental problems as simultaneously social and political-economic, shot through with unequal power relations. This orientation distinguishes political ecology from similar academic fields such as ecological economics, which seeks to expand economic theory to include the natural world and a wider range of human values (Costanza 
1992; Leff 2015), and apolitical approaches such as market environmentalism that dominate the policy world (Anderson and Leal 2001).

However, while political ecology has been lauded for its commitment to social and environmental justice, its 'liberatory potential' (Peet and Watts 1996) has yet to be fully realized, in part because its astute deconstruction of apolitical perspectives has only rarely been accompanied by alternative visions of development or recommendations for change (Blaikie 1999; Robbins 2012; Walker 2006). While political ecology is critical for understanding the contours and drivers of - and more equitable solutions to - the current environmental crisis, analyses that remain in the halls of academia are insufficient for the monumental task at hand (Blaikie 2008, 2012). What is needed is a political ecology that joins public debates on environmental change and strives to shape the consciousness of civil society towards an integrated view of Earth Stewardship. As I conceive it, public political ecology is a political, ethical and educational project influenced by Antonio Gramsci's work on the philosophy of praxis. For Gramsci, the unity of theory and practice, or praxis, is especially important during transitional moments in history, periods of massive upheaval and crisis (Gramsci 2012). These moments offer an acute opportunity for new ideas and practices to be disseminated. The ecological/economic crisis inherent in the Anthropocene provides just such a terrain, opening up the space in which new "modes of thought" or "conceptions of the world" can take hold, facilitating potentially radical social and environmental transformation (Gramsci 2012; Wainwright 2010). At its best, PPE might serve as a community of praxis where stakeholders in- and outside the academy work to develop an Earth Stewardship that integrates environmental sustainability and social justice and makes careful yet powerful use of innovations from public geographies such as participatory action research and mapping, service learning and social media. Public political ecology is a means by which political ecologists can finally make good on the field's emancipatoryclaims.

\section{Earth Stewardship: ethical practice in the age of "the Anthropocene"}

The term Anthropocene can be a type of apolitical ecology (Clarke-Sather et al. 2017). As a way of naming the current crisis, "the Anthropocene" blames changes affecting Earth systems on the human species as a whole, when they might more appropriately be attributed to the fossil fuel economy and the rise of capitalism (Malm and Hornborg 2014; Moore 2014). Despite some debate about its origins, most scholars link the Anthropocene's "take off" to the Industrial Revolution in Britain and the United States that advanced capitalism through the power of fossil fuels (Crutzen 2002b; Steffen et al. 2007; Zalasiewicz et al. 2010). Furthermore, the Anthropocene's second stage, beginning in 1945 and called the Great Acceleration, was marked by rapid and widespread economic growth, urbanization and agricultural modernization as the industrial model of development from the Global North was transferred to and adopted by countries of the Global South as they transitioned out of colonialism (Hart 2001, 2009; Steffen et al. 2007). Some scholars have advocated for the descriptor Capitalocene to underscore the role of the market economy and fossil-fuel- based development in producing today's ecological crisis (Haraway 2015; Moore 2017).

In mainstream environmental scientific usage, the Earth Stewardship concept can also be apolitical (Ogden et al. 2011; Sayre et al. 2013). Some ecologists employ the term Earth Stewardship to posit a new and final stage of the Anthropocene, one marked by the growing awareness of human impact on the planet and a resultant desire to mitigate harm (Ogden et al. 2011; Rozzi et al. 2015; Steffen et al. 2007, 2011). But this concept of stewardship can extend the same analytical problems as the Anthropocene, and furthermore implies a focus on solutions that often prioritize technological fixes such as geo-engineering or market-based action (Steffen et al. 2011). These efforts parallel longstanding strategies that fail to address the root causes of global environmental change and more recent strategies that commodify nature, both of which unwittingly reproduce historical inequities and environmental injustices (Heynen et al. 2007; Osborne 2015).

Despite these flaws, the Anthropocene remains a powerful narrative that, when wielded from a political ecology perspective, can mobilize action in progressive ways (Lovbrand et al. 2015); the same can be said for Earth Stewardship. In this article, I adopt a political ecological understanding of both the Anthropocene and Earth Stewardship, placing them within a framework of social and environmental justice that insists on the intimate integration of science and socio-natural systems. This framework provides the theoretical foundation 
for pursuing ethical action in this moment of crisis, a project that requires the development of interdisciplinary research methodologies and partnerships with diverse stakeholders not only as research subjects but as co-producers of knowledge.

\section{Political ecology: politics and engagement}

Political ecology is a field that coheres around a set of commitments to critical social theory, rich empirical research (sometimes employing mixed qualitative and quantitative methods), and social and environmental justice (Blaikie 2012; Bridge et al. 2015; Paulson et al. 2003; Robbins 2012). The explicit attention to justice, particularly in relation to marginalized or exploited communities and landscapes, has allowed for the field to develop a robust theory of power and politics (Asher 2014; Forsyth 2008; Peet and Watts 1996; Walker 2006). Still, despite these strengths and the fact that political ecology emerged as a critique of cultural ecology's lack of attention to political economy and other power relations, the field has since the 1990s been challenged for its 'remarkable lack of politics', particularly in the sense of micro- politics, or what Watts has referred to as the "rough and tumble of everyday life"2 (Watts 1990: 128-29; Peet and Watts 1996; Walker 2007). This claim has catalyzed sustained debate and a groundswell of literature exploring the theory and practice of politics, relevance and engagement (Bryant 1991; Escobar 1996; Forsyth 2008; Walker 2007).

Early work on political ecology adopted a Marxist approach and focused on broad themes such as soil erosion, land degradation, deforestation and famine to illuminate the political-economic drivers of environmental change (Blaikie and Brookfield 1987; Hecht 1985; Peluso 1992; Watts 1983). Through its attention to scale, this work countered dominant narratives that blamed population growth and peasants for environmental degradation, instead foregrounding political economic factors. In the 1990s, the theoretical tide changed from Marxism to poststructuralism. Political ecologists increasingly began to draw on the work of Foucault to explore the ways in which everyday people negotiated and struggled over resource access, paying attention to micro-politics in communities, households and workplaces and historicizing them within broader geographic contexts (Escobar 1996; Paulson et al. 2003; Peet and Watts 1996). Peet and Watts introduced liberation ecologies as "a more robust political ecology which integrates politics more centrally, draws upon aspects of discourse theory which demands that the politics of meaning and the construction of knowledge be taken seriously" (1996: 3).

Certainly, insights from poststructuralism have bolstered political ecology's ability to deconstruct entrenched narratives and understand subjectivity and micro-politics. Again, though, while the poststructural approach promised to deliver a more liberatory political ecology, this goal has yet to be fully realized in practice (Walker 2006, 2007). Without some kind of roadmap or set of recommendations, the emphasis on deconstruction and critique can discourage active engagement and destabilize key categories of identity and difference around which marginalized groups often mobilize (Blaikie 2012; Fuller and Kitchin 2004). In response, feminist political ecologists have analyzed politics by treating gender as a critical variable that also intersects with other forms of identity such as race, class, and ethnicity that together shape access and control over resources (Elmhirst 2011; Mollett and Faria 2013; Rocheleau et al. 1996). Others have (re)turned to Gramsci's call to engage the cultural politics of nature (Moore 1993, 2005; Yeh 2007).

A recent and exciting wave of scholarship has sought to more explicitly develop a Gramscian approach to political ecology, which can deepen and sharpen the possibilities of politics and engagement (Ekers et al. 2009; Karriem 2009; Loftus 2013; Mann 2009; Perkins 2011). A Gramscian political ecology is never merely academic or analytical, but explicitly political and normative (Ekers et al. 2009; Perkins 2011); pays attention to economic relations as well as the moral field of ethics—i.e. the "ethicopolitical" (Mann 2009); and provides

\footnotetext{
${ }^{2}$ While Blaikie may have overlooked micro-politics in his early writings, his work overall exemplified an applied and practical orientation, particularly his critique of dominant development narratives (Forsyth 2008; Rocheleau 2008; Turner 2014; Walker 2007). In the introduction to The political economy of soil erosion in developing countries, Blaikie wrote "[this] is not a neutral book. It takes sides and argues a position because soil erosion is a political-economic issue, and even a position of so-called neutrality rests upon partisan assumptions" (1985: 1) (emphasis in original). Nevertheless, the perceived lack of politics in this work unleashed a rise in political ecological writing seeking to more deeply engage multiple forms of politics.
} 
an expanded view of power through the concept of hegemony, which is enacted through complex forms of force and consent that play out in historically and geographically specific ways (Karriem 2009). Furthermore, a Gramscian political ecology highlights the importance of culture and ideology for understanding environmental resource conflicts and reads struggles over resources as simultaneously struggles over meaning (Berry 1993; Moore 1993, 1996), recognizing the dialectical and mutually constitutive relationship between nature and society (Karriem 2009; Loftus 2013). For Gramsci (2012), praxis is a "critico-practical activity" whereby theory must be put into action to be made meaningful (Blaikie 2012).

In the 1990s, feminist approaches to political ecology were the first to take engaged scholarship seriously as a means of empowering communities (Rocheleau et al. 1996). Central to these efforts was an emphasis on power-knowledge, environmental rights and justice, and grassroots activism. For example, Fortmann (1996) argues that community-based participatory research methods such as resource mapping are not only an effective form of data collection but a means of empowering village researchers as well as their larger communities. While less connected to political-economic critique, these early forays insisted on taking into account the politics of knowledge production.

Political ecologists have also engaged in the realm of public policy, though the relationship is often tense and ambivalent (Blaikie 2008; Walker 2006). It is typically assumed within public policy studies that scholars who engage in policy are objective and simply provide information for state institutions to interpret and implement; the policy world is thus often at odds with political ecology's sharp critiques and explicitly normative commitments. Nevertheless, many political ecologists work directly in the policy realm, carefully navigating the landmines of cooptation and compromise (Rocheleau 2008; Walker 2006). ${ }^{3}$ Others argue that political ecologists can work with allied partners-for example, NGOs, philanthropists, the media and communities - to effect a longer term and more indirect strategy to influence policy (Blaikie 2008; Rocheleau 2008; Walker 2007). Their interventions suggest that the boundaries between policy and politics may in fact be quite porous, a reality Bebbington highlights by using the Spanish term la política, which describes both policy and politics, signaling that politics is the ongoing struggle over the allocation of resources and meaning established in fixed policies (2014, 2015).

Finally, political ecologists concerned with engagement have also worked with social and environmental justice movements, which is no real surprise given the field's long-established relationship with activism and attention to marginalization (Blaikie 2012; Escobar 1998; Forsyth 2008; Heynen and Van Sant 2015; Robbins 2012; Walker 2007). This type of interaction has been described by Rocheleau as practical political ecology, which she defines as an "experimental form of critical and applied research in search of more democratic and effective models of collaboration with social movements, NGOs and grassroots groups" (2008: 723). For Walker, popular political ecology has similar goals, "t[ying] research directly to activist efforts to improve human wellbeing and environmental sustainability through various forms of local, grassroots activism and organization" (2007: 364). Heynen and Van Sant (2015) see activism as a form of direct-action politics (i.e. operating outside formal state apparatus and logics) that can provide insights for more radical forms of engagement within political ecology. Meanwhile, Dwyer and Baird (2014) argue that, whether engaging with policymakers, social movements, or other scientists, action ought to be 'simultaneously ethical and strategic'a form of principled engagement. However one articulates the particulars of the arrangement, the field's longstanding engagement with social movements and activism is likely to strengthen, particularly in these challenging political-ecological times (Batterbury 2016; Heynen and Van Sant 2015).

In short, political ecologists have deployed a range of strategies to engage the wider world through policy and activism. But whatever its insights, missing from this literature is engagement with broader publics within civil society. A complex and highly debated term, "publics" can be understood to connote a diverse civil society within the public sphere who engage in dialog and can influence democratic political processes (Fraser 1990; Habermas 1991). The monopolization and bias of mainstream media has fueled the need for new forms of engagement and outreach to these publics, and the expansion of social media outlets offers such a

\footnotetext{
${ }^{3}$ Political ecologists who have engaged in policy domains include Kiran Asher, Anthony Bebbington, Piers Blaikie, Diana Liverman, Joshua Muldavin, and Dianne Rocheleau.
} 
possibility. Here insights from 'public geographies' can inform PPE, with their emphasis on the politics of relevance.

\section{Public geographies and the politics of relevance}

The public turn in the discipline of geography has emphasized the importance of relevance, engaged scholarship, participatory methods and the use of social media; key contributions to the field of PPE. Geography has long exhibited a practical orientation, and in the late 1960s and early 1970s critical human geographers initiated an important debate about the discipline's relevance (Chisholm 1971; Oglesby 2006; Staeheli and Mitchell 2005). Relevance is broadly understood as the extent to which academic research moves beyond the academy to reach the wider world. As society is, of course, composed of multiple publics with diverse interests, it is essential to ask - to whom is our work most relevant and who ultimately benefits from our research (Dwyer and Baird 2014; Harvey 1974)?

Taking these questions as a starting point, public geography operates in multiple realms of engagement: applied policy-oriented research serving the needs of a particular state client, scholar-activism working with NGOs and grassroots social movements, and civil society (Blomley 2008; Castree 1999; Chatterton 2006; Derickson and Routledge 2015; Martin 2001; Martin and Sunley 2010; Peck 1999; Pulido 2008). In his 2005 American Association of Geographers (AAG) presidential address, Alexander Murphy called on geographers to participate more actively in public spheres and debates (Murphy 2006). While such work logically entails engaging civil society publics, to do so does not mean ignoring the realm of policy. By transforming societal understanding of an issue, public engagement and other actions can lead to more progressive policy outcomes (Massey 2002; Murphy 2006; Ward 2006). Ultimately, whether directly working with policymakers, social movements or other societal groups, the goal of public geography is to generate knowledge that in some way makes the world a more socially just and environmentally sustainable place (Mitchell 2008; Murphy 2006). Given our privileged position as knowledge producers with relative freedom of expression, academics have a responsibility to share knowledge widely toward this end (Asher 2014; Kitchin and Hubbard 1999).

Public geographers employ various approaches, including participatory and decolonizing methods. Participatory Action Research (PAR) is an approach that challenges traditional forms of research seen as hierarchical and extractive, and instead attempts to democratize data collection, choice of questions, and analysis by working collaboratively with non-academic partners in the co-production of knowledge (Cahill 2007; Kindon et al. 2009; Pain et al. 2013). PAR is largely distinguished from other approaches in that its goal is to not only study and analyze the world, but to advance social justice goals (Cahill 2007; Pratt 2000). One form of PAR, participatory mapping, aims to address critical concerns surrounding traditional cartography and Geographic Information Systems (GIS), particularly questions of uneven access and power, the politics of representation, and the reliance on expert knowledge by including communities directly in the mapping process (Bryan 2015; Elwood 2006; Nietschmann 1995; Peluso 1995). Participatory mapping and GIS, which represent a diverse set of cartographic practices, are perhaps the most controversial of PAR methodologies (Bryan 2015; Elwood 2006). Critics are not convinced that such participatory projects can avoid the more general dangers of mapping practices, i.e. fixing dynamic processes, uneven power relations, and Cartesian ways of knowing that reinforce problematic dualisms between nature and society (Bryan 2015; Rocheleau 2005). More extreme outcomes of participatory GIS can edge problematically toward a type of geopiracy, ${ }^{4}$ as the unethical practices of the Bowman Expedition, which extracted geographic information from communities in Oaxaca, Mexico, without disclosing ties to the US military, clearly demonstrate (Bryan 2015; Wainwright 2012). Given these valid concerns surrounding PAR in general and participatory mapping in particular, do we abandon these tools all together? I agree with Sarah Elwood (2006), who argues that the stakes are too high to abandon participatory methods and that we must instead continue to employ them, being particularly cognizant of politics and power.

Another increasingly important tool in critical public geography is social media, including blogs, social networks, photo and video sharing, and collectively authored sites such as Wikipedia (Kitchin et al. 2013, Sui

\footnotetext{
${ }^{4}$ Geopiracy refers to the extraction of geographic information from communities in order to subvert land tenure, enclose
} land, grab resources or as part of counter-insurgency efforts. 
and Goodchild 2011). Geographers of all ranks, including graduate students, are increasingly utilizing social media to reach broader publics (Kitchin et al. 2013). At best, this activity can form the basis for a type of "digital praxis", facilitating timely critical interventions and creating new and empowered relationships between academics and activists (Kitchin et al. 2013). It can also provide an alternative to mainstream media and has been used by social movements for organizing and mobilization (Juris 2012), while challenging academics to think differently about how we pose research questions, articulate ideas, and disseminate our writing (Kitchin et al. 2013). However, social media raises a thornier set of questions, particularly related to issues of unequal access and representation inherent in a highly commercialized system of media, and the contribution of social media to effective rather than tokenistic activism (Carroll and Hackett 2006; Valenzuela 2013). While these concerns should give public scholars pause, as like participatory mapping social media comprises tools that are too laden with power to ignore, if used in critically reflexive ways, it can provide an important digital space for collaboration, alliance-building and engagement (Kitchin et al. 2013; Sui and Goodchild2011).

Of course, not all scholars desire to use social media or disseminate their work in public ways, i.e. by writing op-eds or producing documentaries. Nor is all scholarship immediately or obviously conducive to such public engagement. In academia, there must always be space for intellectual exploration to advance theory and basic research (Lave 2014). Public geography is therefore practiced by scholars who are compelled to engage the wider world and who believe they have research that is important and timely to share (Castree 2006; Murphy 2006). For these scholars, committing to public engagement is not without risks and challenges (Fuller 2008; Hale 2008; K. Mitchell 2008). Engaged scholarship takes time and is rarely recognized for academic promotion and tenure, which means that it is often conducted by mid-career and senior faculty (Castree 2013, Pulido 2008). In addition, some academics fear that engagement, particularly in the form of scholar-activism, may taint their scholarship as somehow non-objective and open to scrutiny (Kitchin and Hubbard 1999; D. Mitchell 2008). As the possibility of neutrality in research has been widely debated, and largely debunked, an ethical stance demands that we be more explicit about the political commitments that inform our work (Martin 2001; Said 1978; Tandon 1988). For political ecologists who are deeply aligned with social justice, the imperative is to conduct ethically-based, rigorous research and to identify the processes, people and places for which, for whom and where participatory action research is needed and desired (Forsyth 2008).

Despite challenges, many engaged scholars do emphasize the moral and social responsibility we have as academics to use our training and access to resources and information for public benefit (Elwood 2006; Kitchin and Hubbard 1999). PPE fully adopts this moral and social responsibility to direct academic training and expertise toward the realization of the field's liberatory potential.

\section{Public political ecology: a community of praxis}

Political ecology has been described as a community of practice, composed of scholars as well as nonacademics in NGOs, state agencies, international institutions and the media, who to varying degrees engage in critique, analysis and action around a range of environmental issues and socio-natural processes (Robbins 2012). While academic political ecologists are highly proficient at analysis, deconstruction and critique, in general they have shown less prowess at proposing solutions and fostering action for social change-in other words, the practice of engagement (Blaikie 2008; Robbins 2012). For their part, NGO actors may focus more on socially engaged actions without adequate attention to the critical tools of theory and/or analysis. As a community of practice, then, political ecology might lack the robust integration of theory and practice, as well as the interaction, constant feedback and collective learning long associated with the term (Lave and Wenger 1991; Wenger 1998). In addition, the term community of practice has increasingly come to signify a managerial tool for profit-making in the private sector (Cox 2005). PPE might accordingly be better described as a community of praxis. As such, PPE is defined as the theoretically-informed practice of a diverse set of actors (which include an important role for academics) who share environmental concerns, collaborate, and coproduce knowledge in order to guide ethical action for Earth Stewardship.

While Gramsci's work is compatible with other critical scholars of praxis—for example Paulo Freire and bell hooks who focus on liberatory pedagogy for people marginalized along lines of race, class and gender 
(Freire 2000; hooks 2014) —it also provides an understanding of the conjuncture, the ways in which political economic and cultural forces come together in critical moments for social transformation. Gramsci's writing on the philosophy of praxis is particularly instructive in developing PPE. While some have argued that Gramsci used the term praxis as a code word for Marxism to avoid the scrutiny of prison guards (Anderson 1976), his work on the philosophy of praxis suggests that he intended it as a way to theorize the relationship between theory and practice as an extension of Marx's work on the Theses on Feuerbach (Loftus 2013; Thomas 2009). For Gramsci, praxis is the reciprocal relationship between thought and action wherein ideas become a material force for emancipatory social change. The philosophy of praxis is an educational and political project that aims to develop and renovate critical thinking within public spheres so as to expand awareness of the politicaleconomic and historical roots of the ideas that constitute common sense (Monasta 2002). The aim is to facilitate coherent thinking and cultivate good sense through which marginalized people are more capable of constructing a "counter-hegemonic politics" necessary for leading their own lives (Gramsci 2012; Karriem 2009: 318). According to Gramsci:

A philosophy of praxis cannot but present itself at the outset in a polemical and critical guise, as superseding the existing mode of thinking and existing concrete thought (the existing cultural world). First of all, therefore, it must be a criticism of "common sense", basing itself initially, however, on common sense in order to demonstrate that "everyone" is a philosopher and that it is not a question of introducing from scratch a scientific form of thought into everyone's individual life, but of renovating and making "critical" an already existing activity. (Gramsci 2012: 330-331)

For Gramsci, praxis starts from the premise that we are all philosophers, and begins with an interrogation of common sense to renovate and make critical "already existing activity" (Gramsci 2012: 331). This process is most appropriately understood and guided by critical theory. Crucially, Gramsci's project does not end with critique but uses it as a spring board for action:

Creating a new culture ... means the diffusion in a critical form of truths already discovered, their "socialisation" as it were, and even making them the basis of vital action, an element of coordination and intellectual and moral order. (Gramsci 2012: 325)

I read this call to unify theory and practice, thought and action, as an invitation to develop communities of praxis, through which we might renew and deepen the liberatory potential of political ecology as a vehicle for Earth Stewardship.

PPE's theoretically-informed action takes place in just such a community of praxis - a diverse and cohesive group of actors who engage with one another horizontally, in and through networks, building alliances. While scholars have rightfully warned 'against the romance of community' (Joseph 2002), in this context community is linked to understandings of the commons as a 'counter-hegemonic project' of collective management that calls into question socially polarizing interventions such as market enclosures and the commodification of nature (Bakker 2007; Karriem 2009; McCarthy 2005: 9). Members of such a community may include academics, NGO staff, civil society groups, journalists, Indigenous Peoples and other marginalized groups, faith-based organizations, concerned citizens, sustainable local business owners, and philanthropists who combine their strengths in research, policy, education, analysis, organizing, production and fundraising toward shared goals and collaborate in ways that amplify outcomes beyond what would be possible by individuals and smaller groups alone. Of course, members of these groups are heterogeneous, situated unequally, and likely to hold different views from one another on specific courses of action. While not without challenges, PPE sees critical, deliberate collaboration and alliance-building as an essential part of producing radical social transformation. According to Gramsci: 
It will be said that what each individual can change is very little, considering his strength. This is true up to a point. But when the individual can associate himself with all the other individuals who want the same changes, and if the changes wanted are rational, the individual can be multiplied an impressive number of times and can obtain a change which is far more radical than at first sight ever seemed possible. (Gramsci 2012:353)

Collaboration within a community of praxis amplifies efficacy and power not only through sheer numbers of individuals joining forces, but also by producing strategic networks and encouraging the tactical co- production of knowledge.

An expansive definition of 'intellectual' is essential here, widening the meaning of collaboration within communities of praxis and deepening PPE's commitment to Latin Americanist, Indigenous and post- humanist proposals to decolonize knowledge production and recognize agency in both the human and non- human worlds, as well as the interconnection of all life (Berkes 2012; Ogden et al. 2011; Sundberg 2014). This understanding of intellectual work can also help interrogate forces that commodify nature and prioritize economic values above the social, cultural and sacred (Polanyi 2001). It is from this expansive sense of purpose that public political ecologists can most effectively analyze, critique and challenge apolitical discourses, paradigms and institutions, and construct alternative visions for social transformation.

\section{Public political ecology: the role of the intellectual}

Gramsci saw the arena of education as central for the liberation of marginalized groups, and he recognized the terrain of struggle in which dominant groups maintain power by securing popular consent as the basis of hegemony (Borg et al. 2002; Hall 1986; Monasta 2002). While he argued that everyone is an intellectual, Gramsci understood philosophical activity performed by formal intellectuals (academics) as critical for winning the cultural and ideological struggles inherent in capitalism and ultimately transforming popular consciousness from common sense to good sense (Monasta 2002). Furthermore, academics provide social and moral authority and have access to research-related resources, and thus have a responsibility to act - particularly in an era of intensifying and interconnected socio-natural crises (Hall 1986; Sayre et al. 2013). Indeed, crises often catalyze the disintegration of what Gramsci called bourgeois hegemony, where bourgeois interests are represented as the interests of all, and these crises then open space for subordinate groups to lead. The ecological crisis inherent in the Anthropocene might provide such a catalyzing effect. While leadership comes from an historic bloc, intellectuals, particularly those from subordinate groups ('organic intellectuals', in Gramsci's terms) provide leadership for society through education, and articulate a broad vision for change that generates new conceptions of the world (Gramsci 2012). In more consistent contact with diverse societal groups, organic intellectuals devise research questions that emerge based on those relationships (Gramsci 2012).

PPE operates at the intersection of research, teaching and service, three pillars of academic work that, within this framework, become deeply entangled and share equal value. Structurally speaking, it can be difficult for academics to pursue such an agenda. While many universities and funding institutions claim to value community-engaged scholarship, in practice there are numerous structural and institutional constraints which relegate this work to the category of 'service', which is least valued for promotion and job security in many Western countries (Whitmer et al. 2010). These barriers can be, more immediately, overcome through a process that carefully triangulates research to simultaneously participate in current theoretical debates, fulfill the interests of non-academic collaborators, and take into consideration broader interests of publics or institutions served by the analysis (Derickson and Routledge 2015). This type of service-oriented research in turn informs critical pedagogy in the classroom, which is an important site for engagement by political ecologists (Jarosz 2004).

While pedagogy is not a common topic in political ecology, some scholars have identified teaching as a neglected site for political praxis (Heyman 2000; Jarosz 2004). Critical pedagogy is an important realm for political ecology, as students represent an obvious public for social change (Jarosz 2004; Jarosz and Johnson 
Bogart 1996; Petrina 2000). Jarosz sees service learning as a valuable pedagogical tool that contributes to a broader project of engaged scholarship, one that makes political ecology more concrete for students by anchoring theory to local issues and concerns (2004). Universities are increasingly forming campuscommunity partnerships which provide students with engagement experiences and communities with needed research, a powerful combination for social change (Peterson 2009). ${ }^{5}$ Alongside decolonizing methodologies for the co-production of knowledge, training in service learning, PAR, ethics in fieldwork and other pedagogical tools are, therefore, central for developing PPE.

Operating in the realm of service, PPE recognizes the moral imperative of scholars to engage in public debates. Political ecologists have both the training and legitimacy to speak to a range of environmental issues and contextualize them historically and geographically. Popular education is therefore centrally concerned with education outside of formal academic spaces. Political ecologists can serve as public intellectuals who engage civil society, address matters of public concern, and offer their opinions on the state of society (Ward 2007). However, the term public intellectual can sound grandiose and often conjures a certain discomfort as a selfdescriptor, leaving many scholars hesitant to assume such a position (Castree 2006). PPE re-conceptualizes this position of the public intellectual, challenging the notion that only a few authoritative scholars can speak, and instead recognizes that as trained academics we are more than qualified to engage in public debates based on our knowledge and expertise. Furthermore, as we are not only scholars but also embedded in particular communities, we can speak from positions of expertise - a type of distanced knowledge, as well as from direct experience-a more intimate knowledge. As we increasingly engage the public from a political ecology perspective, as scholars in a community of praxis, we begin to shift public debate, activating a critique of common sense and more liberatory engagement in the world. Again this returns us to Gramsci's insistence that everyone is a philosopher, which widens the meaning and practice of the intellectual beyond a select few (2012).

\section{Already existing public political ecologies}

Political ecologists are already strategically engaging multiple publics through, for example, blogs, opeds, documentaries and Massive Open Online Courses (MOOCs). ${ }^{6}$ Coordinated examples of publically engaged political ecology based at universities include the Global Atlas of Environmental Justice or the EJAtlas $^{7}$ at the Autonomous University of Barcelona, and the Public Political Ecology Lab at the University of Arizona. The EJAtlas is a participatory and collaborative project for mapping global environmental conflicts coordinated by the Institute of Environmental Science and Technology (ICTA) ${ }^{8}$ (Temper et al. 2015). EJAtlas is a "teaching, networking and advocacy resource" that aims to make environmental conflicts visible around the world (EJAtlas 2016). It is a political and educational project through which researchers work with social movement activists to identify resource conflicts and make that information accessible to the public through a web platform. Detailed summaries of environmental conflicts and key stakeholders allow for tactical advocacy, alliance-building and action. EJAtlas builds a community of praxis by using theories of environmental justice and PAR methodologies to unite scientists, activist organizations, and policymakers around issues of ecological distribution while rendering resource struggles visible to broader publics (Temper et al. 2015).

Another example of political ecology in action is the Public Political Ecology Lab (PPEL), which operates in the realms of research, teaching and service. Recognizing the importance of a political ecology perspective for long-term social and environmental justice and its relative absence from public debate, in 2011,

\footnotetext{
${ }^{5}$ RESEED, founded by political ecologist Haripriya Rangan with her former students in Australia, is a social enterprise aiming to run field study programs that have a long-term commitment to host communities in southern Africa (Rangan 2017). [http://www.reseed.com.au]

${ }^{6}$ See the Public Political Ecology Lab website for examples of scholar's engaged scholarship [http://ppel.arizona.edu].

${ }^{7}$ Initially a project of EJOLT (Environmental Justice Organisations, Liabilities and Trade), the EJAtlas is being expanded and coordinated by the programs of ENVJUSTICE (Director: Joan Martínez-Alier) [http://www.envjustice.org] and ACKnowl-EJ [http://acknowlej.org] (Director: Leah Temper).

${ }^{8}$ Institut de Ciència i Tecnologia Ambientals, Universitat Autònoma de Barcelona.
} 
I launched the PPEL with graduate students at the University of Arizona's School of Geography and Development. The PPEL is a collaborative project of theoretically-informed engaged scholarship that provides a platform for public education, supports the research needs of NGOs and social movements, and provides pedagogical resources to scholars and students of political ecology. The Lab offers a digital space for political ecologists to communicate their research to broader publics through the use of social media, blogs, video and photo essays. The PPEL's website features special-focus blog posts on timely environmental issues by political ecologists with expertise on the subject. It also hosts short videos featuring established and emerging political ecologists on their practice of engaged scholarship. These videos are an important pedagogical tool that highlights the many ways in which political ecologists engage the public, which are often not apparent from their published work or faculty websites. The PPEL thus provides a platform for popular education and radical pedagogy.

One of the Lab's most recent initiatives is the Climate Alliance Mapping Project (CAMP) ${ }^{9}$, a collaborative effort among academics, environmental NGOs and Indigenous organizations to address climate change by creating interactive multimedia maps and a web portal that aims to engage multiple publics, build activist and community networks and inform policy decisions. Following Gramsci's philosophy of praxis, it aims to unite theory and practice through participatory action research and mapping. The main objectives of CAMP are to build coalitions among climate justice organizations and to provide a platform for visually powerful digital stories of fossil fuel development and renewable energy transitions. CAMP's research direction is critically informed by political ecology theories of marginalization, resource conflicts, social movements and the commons. It is motivated by commitments to social and environmental justice; furthermore, this praxis takes place in communities, keeping in dynamic communication with the work and priorities of environmental organizations and Indigenous groups. In this way, CAMP works to construct a counter-hegemonic intellectualmoral bloc, an essential part of the philosophy of praxis, through collaborations with diverse actors, synthesizing information and presenting it on multimedia platforms in visually powerful and publically accessible ways (Gramsci 2012).

From its founding, CAMP unfolded within a broad community of praxis. The idea of CAMP was developed through conversations with Amazon Watch executive staff ${ }^{10}$, an environmental NGO that partners with Indigenous communities to assert their rights and protect Amazon rainforests. As part of an alliance of over 50 environmental and Indigenous rights organizations working for climate justice, Amazon Watch expressed interest in a map that identifies priority areas for keeping fossil fuels underground. This map takes as a starting point the science that recognizes the need to leave fossil fuels in reserves and unburned in order to hold global temperatures below a 2-degree Celsius increase over pre-industrial levels. To reach this target, McGlade and Ekins (2015) argue that from 2010 to 2050 a third of global oil reserves, half of gas reserves and over 80 percent of current coal reserves should be left underground. Their study employs an economic calculus to determine these sites; in contrast, CAMP adopts a political ecology approach that identifies ecologically and culturally important areas as priority zones, according to the values of the environmental and Indigenous organizations with which we are collaborating. In the future, digital stories will be added to the map to amplify the voices of marginalized communities and encourage organizations across the Americas to expand alliances in support of climate justice. By advancing strategies for "complex alliances" (Hall 1986), again, this project is solidly aligned with a Gramsican perspective.

EJAtlas and CAMP are ongoing experiments in global counter-mapping that use GIS to complement activist struggles for environmental and climate justice. Largely based on PAR methods and participatory mapping, these efforts aim to move beyond critique and deconstruction towards co-producing knowledge to

\footnotetext{
${ }^{9}$ The CAMP team responsible for launching the project includes University of Arizona faculty members - Drs. Jamie A. Lee and Benedict Colombi, and Geography graduate students: Remington Franklin, Megan Mills-Novoa and Kristine (Stina) Janssen. Funding from Robert and Patricia Switzer Foundation made the project possible. Website [https://climatealliancemap.org]

${ }^{10}$ The idea for CAMP emerged from conversations with Amazon Watch's founder and former Executive Director, Atossa Soltani, who currently serves as the organization's Board President, and the organization's current Executive Director Leila Salazar-López.
} 
serve social movements on the ground (Temper and Del Bene 2016). To be sure, these nascent projects are likely to suffer some of the same challenges of earlier PAR and participatory mapping efforts, and even experience new ones. For example, we might question the implications of making visible environmental conflicts around highly political resources such as oil, and exposing the stories of marginalized peoples on the front lines. These types of ethical issues must be considered and addressed with great care in ways that move beyond conventional systems of research ethics as applied by the Institutional Review Board. Furthermore, researchers involved in projects like EJAtlas and CAMP must be critically reflexive and rigorously attentive to issues of power and access inherent to the process.

\section{Conclusion}

The Anthropocene's social and environmental disruptions demand new forms of engagement from political ecologists compelled to take action. I have introduced Public Political Ecology as one perspective and approach that might support the development of an integrated Earth Stewardship. Informed by a Gramscian perspective, PPE is a community of praxis within which academics play important roles in renovating coherent and critical thinking activities that transform popular consciousness, shifting common sense to good sense. The ecological/economic crises of the Anthropocene provide the terrain on which this type of coherent thinking and new conceptions of the world can take root. This perspective activates the critical capacity already existing in society and lays a pathway for the possibility of a more environmentally sustainable and socially just world. In conclusion, PPE exhibits five key characteristics that make it a particularly useful framework for supporting Earth Stewardship:

1) PPE is a political, educational and ethical project of theoretically-informed engaged scholarship.

2) It is informed by Gramsci's philosophy of praxis, which describes the reciprocal relationship between theory and practice, and recognizes the power of ideas as a world- changing material force.

3) It recognizes an important role for academics within a community of praxis whose diverse actors share environmental concerns, collaborate, build alliances and co-produce knowledge in pursuit of effective action.

4) It operates in the realm of research, teaching and service, carefully triangulating research to both serve the needs of community partners while meeting academic requirements, and making use of critical pedagogical methods that acknowledge students as a crucial public for social change.

5) It is committed to the decolonization of knowledge production and therefore aims to employ participatory action research and mapping methodologies used in critically reflexive ways, with ongoing attention to the ethics of publicengagement.

Making a political ecology perspective more accessible to broader publics, training students to conduct theoretically-informed engaged scholarship, and supporting various marginalized groups, organizations and social-movements in alliance-building is the heart of public political ecology, and essential for an integrated and ethical Earth Stewardship. The gravity of our current political, ecological and economic state demands nothing less.

\section{References}

Anderson, P. 1976. The antinomies of Antonio Gramsci. New Left Review I/100: 5-78.

Anderson, T. and D. Leal. 2001. Free market environmentalism. New York: Palgrave. 
Asher, K. 2014. The doers and the done for: interrogating the subjects and objects of engaged political ecology. ACME: An International E-Journal for Critical Geographies 13(4):489-496.

Bakker, K. 2007. The "commons" versus the "commodity": alter-globalization, anti-privatization and the human right to water in the global south. Antipode 39(3): 430-455.

Clarke-Sather A., B. Crow-Miller, J.M. Banister, K. Anh Thomas, E.S. Norman and S.R. Stephenson. 2017. The shifting geopolitics of water in the Anthropocene. Geopolitics 22(2): 332-359.

Barnosky, A.D., N. Matzke, S. Tomiya, G.O. Wogan, B. Swartz, T.B. Quental, C. Marshall, J.L. McGuire, E.L. Lindsey, K.C. Maguire and B. Mersey. 2011. Has the Earth's sixth mass extinction already arrived? Nature 471(7336): 51-57. Researchgate

Batterbury, S.P.J. 2016. Ecología política: relevancia, activismo y posibilidades de cambio. Ecología Política 50: 45-54. In English- Researchgate

Bebbington, A.J. 2014. The endogenous scholar: porous boundaries and travelling ideas in development. Third World Quarterly 35(3): 520-523.

Bebbington, A.J. 2015. At the boundaries of la política: political ecology, policy networks and moments of government. In Perreault, T., G. Bridge and J. McCarthy (eds.). Routledge handbook of political ecology. London: Routledge. Pp. 198-208.

Berkes, F. 2012. Sacred ecology. London: Routledge.

Berry, S. 1993. No condition is permanent: the social dynamics of agrarian change in sub-Saharan Africa. Madison: University of Wisconsin Press.

Blaikie, P.M. 1985. The political economy of soil erosion in developing countries. London: Longman.

Blaikie, P.M. 1999. A review of political ecology. Zeitschrift für Wirtschaftsgeographie 43(1): 131-147.

Blaikie, P.M. 2008. Epilogue: towards a future for political ecology that works. Geoforum 39(2): 765-772. Researchgate

Blaikie, P.M. 2012. Should some political ecology be useful? The inaugural lecture for the Cultural and Political Ecology Specialty Group, Annual Meeting of the Association of American Geographers, April 2010. Geoforum 43(2): 231-239.

Blaikie, P.M. and H.C. Brookfield, 1987. Land degradation and society. London: Longman.

Blomley, N.K. 2008. Activism and the academy. In H. Bauder and S. Engel-Di Mauro (eds.) Critical geographies: a collection of readings. Kelowna: Praxis (e)Press. Pp. 28-32.

Borg, C., J.A. Buttigieg and P. Mayo (eds.). 2002. Gramsci and education. Lanham: Rowman and Littlefield.

Bridge, G., J. McCarthy and T. Perreault 2015. Editor's introduction. In Perreault, T., G. Bridge and J. McCarthy (eds.) Routledge handbook of political ecology. London: Routledge. Pp. 3-18.

Bryan, J. 2015. Participatory mapping. In Perreault, T., G. Bridge and J. McCarthy (eds.) Routledge handbook of political ecology. London: Routledge. Pp. 249-262.

Bryant, R.L. 1991. Putting politics first: the political ecology of sustainable development. Global Ecology and Biogeography Letters 1(6): 164-166.

Cahill, C. 2007. The personal is political: developing new subjectivities through participatory action research. Gender, Place and Culture 14(3): 267-292.

Carroll, W.K. and R.A. Hackett. 2006. Democratic media activism through the lens of social movement theory. Media, Culture and Society 28(1): 83-104.

Castree, N. 1999. Out there? In here? Domesticating critical geography. Area 31(1): 81-86. Castree, N. 2006. Geography's new public intellectuals? Antipode 38(2): 396-412.

Castree, N. 2013. The struggle over geography: prospects for advancing public pedagogy. Dialogues in Human Geography 3(2): 163-166.

Castree, N. 2014. The Anthropocene and geography I: the back story. Geography Compass 8(7): 436-449. 
Chapin III, F.S., M.E. Power, S.T.A. Pickett, A. Freitag, J.A. Reynolds, R.B. Jackson, D.M. Lodge, C. Duke, S.L. Collins, A.G. Power and A. Bartuska. 2011. Earth Stewardship: science for action to sustain the human-earth system. Ecosphere 2(8): art89.

Chatterton, P., 2006. "Give up activism" and change the world in unknown ways: or, learning to walk with others on uncommon ground. Antipode 38(2): 259-281.

Chisholm, M. 1971. Geography and the question of 'relevance'. Area 3(2): 65-68.

Costanza, R. 1992. Ecological economics: the science and management of sustainability. New York: Columbia University Press.

Cox, A. 2005. What are communities of practice? A comparative review of four seminal works. Journal of Information Science 31(6): 527-540.

Crutzen, P.J. 2002a. Geology of mankind. Nature 415(6867): 23.

Crutzen, P.J., 2002b. The "anthropocene". Journal de Physique IV 12(10): 1-5.

Crutzen, P.J. and E.F. Stoermer. 2000. The Anthropocene. IGBP Newsletter 41: 7-18.

Daniel, J. 2012. Making sense of MOOCs: musings in a maze of myth, paradox and possibility. Journal of Interactive Media in Education 2012(3): Art 18.

Derickson, K.D. and P. Routledge. 2015. Resourcing scholar-activism: collaboration, transformation, and the production of knowledge. The Professional Geographer 67(1): 1-7.

Dwyer, M.B. and I.G. Baird. 2014. Principled engagement: political ecologists and their interactions outside the academy introduction to a set of short interventions. ACME: An International Journal for Critical Geographies 13(4): 473-477.

Ebben, M. and J.S. Murphy. 2014. Unpacking MOOC scholarly discourse: a review of nascent MOOC scholarship. Learning, Media and Technology 39(3): 328-345.

EJ Atlas. 2016. EJAtlas: mapping environmental justice. Environmental Justice Atlas. Institut De Ciència I Tecnologia Ambientals - Universitat Autònoma de Barcelona (ICTA - UAB). Web. December 2016. [http://ejatlas.org].

Elmhirst, R. 2011. Introducing new feminist political ecologies. Geoforum 42(2): 129-132.

Elwood, S. 2006. Critical issues in participatory GIS: deconstructions, reconstructions, and new research directions. Transactions in GIS 10(5): 693-708. Researchgate

Elwood, S. 2008. Volunteered geographic information: future research directions motivated by critical, participatory, and feminist GIS. GeoJournal 72(3-4): 173-183. Researchgate

Escobar, A. 1996. Construction nature: elements for a post-structuralist political ecology. In Peet, R. and M.J. Watts (eds.) Liberation ecologies: environment, development, social movements. London: Routledge.

Escobar, A. 1998. Whose knowledge, whose nature? Biodiversity, conservation, and the political ecology of social movements. Journal of Political Ecology 5(1): 53-82.

Forsyth, T.J. 2008. Political ecology and the epistemology of social justice. Geoforum 39(2): $756-764$. Fortmann, L. 1996. Gendered knowledge: rights and space in two Zimbabwe villages. In Rocheleau, D.E., B. Thomas-Slayter, and E. Wangari (eds.). Feminist political ecology: global issues and local experience. London: Routledge. Pp. 211-223.

Fraser, N. 1990. Rethinking the public sphere: a contribution to the critique of actually existing democracy. Social Text 25/26: 56-80.

Freire, P. 2000[1970]. Pedagogy of the oppressed. London: Bloomsbury Publishing.

Fuller, D. 2008. Public geographies: taking stock. Progress in Human Geography 32(6): 834-844.

Fuller, D. and Kitchin, R. 2004. Radical theory/critical praxis: academic geography beyond the academy. In Fuller, D. and R. Kitchin. Radical theory/critical praxis: making a difference beyond the academy. Kelowna: Praxis EPress. Pp.1-20.

Gibson-Graham, J.K. and G. Roelvink. 2010. An economic ethics for the Anthropocene. Antipode 41(s1): 320346. 
Gramsci, A., 2012[1929-1935]. Selections from the prison notebooks of Antonio Gramsci. Edited by Hoare, Q. and G. Nowell-Smith. New York: International Publishers.

Graham, M., S. Hale and M. Stephens. 2012. Featured graphic: digital divide: the geography of internet access. Environment and Planning A 44(5): 1009-1010. Researchgate

Habermas, J. 1991. The structural transformation of the public sphere: an inquiry into a category of bourgeois society. Cambridge: MIT Press.

Hale, C.R. 2008. Engaging contradictions: theory, politics, and methods of activist scholarship. Berkeley: University of California Press.

Hall, S. 1986. Gramsci's relevance for the study of race and ethnicity. Journal of Communication Inquiry 10(5): 5-27.

Haraway, D., 2015. Anthropocene, Capitalocene, Plantationocene, Chthulucene: making kin. Environmental Humanities 6: 159-165.

Hart, G. 2001. Progress reports: development critiques in the 1990s: culs de sac and promising paths. Progress in Human Geography 25(4): 649-658. Academia

Hart, G. 2009. D/developments after the meltdown. Antipode 41(s1): 117-141. Academia

Harvey, D. 1974. What kind of geography for what kind of public policy? Transactions of the Institute of British Geographers 63: 18-24.

Harvey, D. 2001. Spaces of capital: towards a critical geography. Edinburgh: Edinburgh University Press; New York: Routledge.

Hecht, S.B. 1985. Environment, development and politics: capital accumulation and the livestock sector in eastern Amazonia. World Development 13(6): 663 - 684.

Heyman, R. 2000. Research, pedagogy, and instrumental geography. Antipode 32(3): 292-307.

Heynen, N., J. McCarthy, S. Prudham and P. Robbins (eds.). 2007. Neoliberal environments: false promises and unnatural consequences. London: Routledge.

Heynen, N. and L. Van Sant. 2015. Political ecologies of activism and direct action politics. In Perreault, T.,G. Bridge and J. McCarthy (eds.) Routledge handbook of political ecology. London: Routledge. Pp. 169178.

hooks, b. 2014. Teaching to transgress. London: Routledge.

Jarosz, L. 2004. Political ecology as ethical practice. Political Geography 23(7): 917-927.

Jarosz, L. and K. Johnson-Bogart. 1996. New concepts of the relationship between college and community: the potential of service learning. College Teaching 44(3): 83-88.

Joseph, M. 2002. Against the romance of community. Minnesota: University of Minnesota Press.

Juris, J.S. 2012. Reflections on \#Occupy Everywhere: social media, public space, and emerging logics of aggregation. American Ethnologist 39(2): 259-279.

Kindon, S., M. Kesby and R. Pain. 2009. Participatory Action Research. In R. Kitchin and N. Thrift (eds.). International encyclopedia of human geography. London: Elsevier. Pp. 90-95.

Kingsford, R.T., J.E. Watson, C.J. Lundquist, O. Venter, L. Hughes, E.L. Johnston, J. Atherton, M. Gawel, D.A. Keith, B.G. Mackey and C. Morley. 2009. Major conservation policy issues for biodiversity in Oceania. Conservation Biology 23(4): 834-840. Academia

Kitchin, R.M. and P.J. Hubbard. 1999. Research, action and 'critical' geographies. Area 31(3): 195-198.

Kitchin, R., D. Linehan, C. O'Callaghan and P. Lawton. 2013. The creation and circulation of public geographies. Dialogues in Human Geography 3(1): 96-102. Academia

Lave, J. and E. Wenger. 1991. Situated learning: legitimate peripheral participation. Cambridge: Cambridge University Press.

Lave, R. 2014. Engaging within the academy: a call for critical physical geography. ACME: An International E-Journal for Critical Geographies 13(4): 508-515.

Leff, E. 2015. Political ecology. a Latin American perspective. Desenvolvimento e Meio Ambiente 35: 29-64. 
Loftus, A. 2013. Gramsci, nature, and the philosophy of praxis. In M. Ekers, G. Hart and S. Kipfer (eds.). Gramsci: space, nature, politics. Oxford: Wiley-Blackwell. Pp. 178-196.

Loftus, A. 2015. Political ecology as praxis, In Perreault, T., G. Bridge and J. McCarthy (eds.) Routledge handbook of political ecology. London: Routledge. Pp. 179-187.

Lubchenco, J. 1998. Entering the century of the environment: a new social contract for science. Science 279(5350): 491-497.

Malm, A. and A. Hornborg. 2014. The geology of mankind? A critique of the Anthropocene narrative. The Anthropocene Review 1(1): 62-69.

Mann, G. 2009. Should political ecology be Marxist? A case for Gramsci's historical materialism. Geoforum 40(3): 335-344

Martin, R. 2001. Geography and public policy: the case of the missing agenda. Progress in Human Geography 25(2): 189-210.

Martin, R. and P. Sunley. 2010. The new economic geography and policy relevance. Journal of Economic Geography 11(2): 357-369.

Massey, D. 2002. Geography, policy and politics: a response to Dorling and Shaw. Progress in Human Geography 26(5): 645-646.

McCarthy, J. 2005. Commons as counterhegemonic projects. Capitalism Nature Socialism 16(1): 9-24.

McGlade, C. and P. Ekins. 2015. The geographical distribution of fossil fuels unused when limiting global warming to $2^{\circ} \mathrm{C}$. Nature 517(7533): 187-190.

Mitchell, D. 2008. Confessions of a desk-bound radical. Antipode 40(3): 448-454.

Mollett, S. and C. Faria. 2013. Messing with gender in feminist political ecology. Geoforum 45: 116-125.

Monasta, A. 2002. Antonio Gramsci: the message and the images. In Borg, C., J.A. Buttigieg and P. Mayo (eds.). 2002. Gramsci and education. Lanham: Rowman and Littlefield. Pp. 67-87.

Moore, D.S. 1993. Contesting terrain in Zimbabwe's eastern highlands: political ecology, ethnography, and peasant resource struggles. Economic Geography 69(4): 380-401.

Moore, D.S. 2005. Suffering for territory: race, place, and power in Zimbabwe. Durham: Duke University Press.

Moore, J.W. 2015. Capitalism in the web of life: ecology and the accumulation of capital. London: Verso.

Moore, J.W. 2017. The Capitalocene, part I: on the nature and origins of our ecological crisis. The Journal of Peasant Studies 44(3): 594-630.

Murphy, A.B. 2006. Enhancing geography's role in public debate. Annals of the Association of American Geographers 96(1): 1-13.

Nietschmann, B. 1995. Defending the Miskito Reefs with maps and GPS: mapping with sail, scuba, and satellite. Cultural Survival Quarterly 18(4): 34-37.

Ogden, L., N. Heynen, U. Oslender, P. West, K.A. Kassam and P. Robbins. 2013. Global assemblages, resilience, and Earth Stewardship in the Anthropocene. Frontiers in Ecology and the Environment 11(7): 341-347.

Oglesby, E. 2006. Research collaboration from a geographer's perspective. Latin American Studies $\underline{\text { Association }}$ Forum 37(4): 19-21.

Osborne, T. 2015. Tradeoffs in carbon commodification: a political ecology of common property forest governance. Geoforum 67: 64-77. Academia

Pain, R., M. Kesby and K. Askins. 2011. Geographies of impact: power, participation and potential. Area 3(2): 183-188. Academia

Pain, R., M. Finn, R. Bouveng and G. Ngobe. 2013. Productive tensions-engaging geography students in participatory action research with communities. Journal of Geography in Higher Education 37(1): 2843. 
Paulson, S., L.L. Gezon and M.J. Watts. 2003. Locating the political in political ecology: an introduction. Human Organization 62(3): 205-217. Academia

Peck, J. 1999. Editorial: grey geography? Transactions of the Institute of British Geographers 24(2): 131- 135.

Peet, R. and M.J. Watts (eds.). 1996. Liberation ecologies: environment, development, social movements. London: Routledge.

Peet, R., P. Robbins and M.J. Watts (eds.). 2010. Global political ecology. London: Routledge.

Peluso, N.L. 1992. Rich forests, poor people: resource control and resistance in Java. Berkeley: University of California Press.

Peluso, N.L. 1995. Whose woods are these? counter-mapping forest territories in Kalimantan, Indonesia. Antipode 27(4): 383-406.

Perkins, H.A. 2011. Gramsci in green: neoliberal hegemony through urban forestry and the potential for a political ecology of praxis. Geoforum 42(5): 558-566.

Peterson, T.H. 2009. Engaged scholarship: reflections and research on the pedagogy of social change. Teaching in Higher Education 14(5): 541-552.

Petrina, S. 2000. The political ecology of design and technology education: an inquiry into methods. International Journal of Technology and Design Education 10(3): 207-237.

Polanyi, K. 2001. The great transformation: the political and economic origins of our time. Boston: Beacon Press.

Power, M.E. and F.S. Chapin III. 2009. Planetary stewardship. Frontiers in Ecology and the Environment. 7(8): 399-399.

Pulido, L. 2008. FAQs: Frequently Asked Questions on being a scholar/activist. In Hale, C. (ed.). Engaging contradictions: theory, politics and methods of activist scholarship. Berkeley: University of California Press. Pp. 341-366.

Rangan, H. 2017. Are social enterprises a radical planning challenge to neoliberal development? In H. Rangan, M.K. Ng, L. Porter and J. Chase (eds.). Insurgencies and revolutions: reflections on John Friedmann's contributions to planning theory and practice. London: Routledge. Pp. 95-104.

Robbins, P. 2012. Political ecology: a critical introduction. Oxford: Blackwell.

Robinson, A.C., J. Kerski, E.C. Long, H. Luo, D. DiBiase and A. Lee. 2015. Maps and the geospatial revolution: teaching a massive open online course (MOOC) in geography. Journal of Geography in Higher Education 39(1): 65-82.

Rocheleau, D.E., B. Thomas-Slayter and E. Wangari (eds.). 1996. Feminist political ecology: global issues and local experience. London: Routledge.

Rocheleau, D.E. 2005. Maps as power tools: locating communities in space or situating people and ecologies in place. In Brosius, P.J, A.L. Tsing and C. Zerner (eds.). Communities and conservation: histories and politics of community-based natural resource management. Walnut Creek: Altamira. Pp. 327-362.

Rocheleau, D.E. 2008. Political ecology in the key of policy: from chains of explanation to webs of relation. Geoforum 39(2): 716-727.

Rockström, J., W. Steffen, K. Noone, Å. Persson, F.S. Chapin, III, E. Lambin, T.M. Lenton, M. Scheffer, C. Folke, H. Schellnhuber, B. Nykvist, C.A. De Wit, T. Hughes, S. van der Leeuw, H. Rodhe, S. Sörlin, Snyder, P.K., R. Costanza, U. Svedin, M. Falkenmark, L. Karlberg, R.W. Corell, V.J. Fabry, J. Hansen, B. Walker, D. Liverman, K. Richardson, P. Crutzen and J. Foley. 2009. Planetary boundaries:exploring the safe operating space for humanity. Ecology and Society 14(2): 32.

Rozzi, R., F.S. Chapin III, J.B. Callicott, S.T. Pickett, M.E. Power, J.J. Armesto and R.H. May Jr. (eds.). 2015. Earth stewardship: linking ecology and ethics in theory and practice. Dordrecht: Springer.

Said, E. 1978. Orientalism. New York: Pantheon. 
Sayre, N.F., R.R. McAllister, B.T. Bestelmeyer, M. Moritz and M.D. Turner. 2013. Earth Stewardship of rangelands: coping with ecological, economic, and political marginality. Frontiers in Ecology and the Environment 11(7): 348-354.

Smith, L.T. 2012. Decolonizing methodologies: research and indigenous peoples. London: Zed.

Staeheli, L.A. and D. Mitchell. 2005. The complex politics of relevance in geography. Annals of the Association of American Geographers 95(2): 357-372.

Steffen, W., P.J. Crutzen and J.R. McNeill. 2007. The Anthropocene: are humans now overwhelming the great forces of nature. AMBIO: a Journal of the Human Environment 36(8): 614-621.

Steffen, W., Å Persson, L. Deutsch, J. Zalasiewicz, M. Williams, K. Richardson, C. Crumley, P. Crutzen, C. Folke, L. Gordon and M. Molina. 2011. The Anthropocene: from global change to planetary stewardship. Ambio 40(7): 739-761. Researchgate

Sundberg, J. 2014. Decolonizing posthumanist geographies. Cultural Geographies 21(1): 33-47.

Tandon, R. 1988. Social transformation and participatory research. Convergence 21(2-3): 5-18.

Temper, L., D. del Bene and J. Martinez-Alier. 2015. Mapping the frontiers and front lines of global environmental justice: the EJAtlas. Journal of Political Ecology 22: 255-278.

Temper, L. and D. Del Bene. 2016. Transforming knowledge creation for environmental and epistemic justice. Current Opinion in Environmental Sustainability 20: 41-49. Researchgate

Thomas, P.D. 2009. The Gramscian moment: philosophy, hegemony and Marxism. Leiden: Brill.

Turner, M.D. 2014. Political ecology and its engagements with conservation and development. ACME: an International Journal for Critical Geographies 13(4): 478-488.

Valenzuela, S. 2013. Unpacking the use of social media for protest behavior: the roles of information, opinion expression, and activism. American Behavioral Scientist 57(7): 920-942.

Wainwright, J. 2010. On Gramsci's 'conceptions of the world'. Transactions of the Institute of British Geographers 35(4): 507-521.

Wainwright, J. 2012. Geopiracy: Oaxaca, militant empiricism, and geographical thought. London: Palgrave Macmillan.

Walker, P.A. 2006. Political ecology: where is the policy? Progress in Human Geography 30(3): 382-395.

Walker, P.A. 2007. Political ecology: where is the politics? Progress in Human Geography 31(3): 363-369.

Ward, K. 2006. Geography and public policy: towards public geographies. Progress in Human Geography 30(4): 495-503.

Ward, K. 2007. Geography and public policy: activist, participatory, and policy geographies. Progress in Human Geography 31(5): 695-705.

Watts, M.J. 1990. Review of 'Land degradation and society' by Piers Blaikie and Harold Brookfield, 1987. Capitalism, Nature, Socialism 4: 123-131.

Wenger, E. 1998. Communities of practice: learning, meaning, and identity. Cambridge: Cambridge University Press.

Whitmer, A., L. Ogden, J. Lawton, P. Sturner, P.M. Groffman, L. Schneider, D. Hart, B. Halpern, W. Schlesinger, S. Raciti and N. Bettez. 2010. The engaged university: providing a platform for research that transforms society. Frontiers in Ecology and the Environment 8(6): 314-321.

Yeh, E.T. 2007. Tropes of indolence and the cultural politics of development in Lhasa, Tibet. Annals of the Association of American Geographers 97(3): 593-612. Researchgate

Zalasiewicz, J., M. Williams, W. Steffen and P. Crutzen. 2010. The new world of the Anthropocene. Environmental Science and Technology 44(7): 2228-2231. 